\title{
Optimalisasi Teknologi Hydroponic dengan Pembangunan Greenhouse sebagai Solusi Ketahanan Pangan di Masa Pandemi
}

\section{Eva Mulyani*1, Redi Hermanto², Ike Natalliasari³ ${ }^{3}$ Muhammad Adi Khairul A4}

\author{
1,2,3Pendidikan Matematika, Fakultas Keguruan dan Ilmu Pendidikan, Universitas Siliwangi, Indonesia \\ ${ }^{4}$ Teknik Informatika, Fakultas Teknik, Universitas Siliwangi, Indonesia \\ *e-mail: $\underline{\text { evamulyani@unsil.ac.id }}^{1}$, $\underline{\text { redihermanto@unsil.ac.id }}^{2}$, $\underline{\text { ikenatalliasari@unsil.ac.id }}^{3}$,
}

\author{
adikhairul@unsil.ac.id $^{4}$
}

\begin{abstract}
Abstrak
Kesulitan pemenuhan kebutuhan pangan masyarakat Kampung Ciganda seharusnya tidak perlu terjadi. Melihat beberapa potensi yang dimiliki seperti luasnya area kebun serta masyarakatnya yang mayoritas berprofesi sebagai petani. Namun karena ketersediaan air saat musim kemarau terbatas, maka hasil panen sayuran seringkali tidak optimal. Faktor lain yang menyebabkan terjadinya gagal panen adalah serangan hama sayuran. Pelaksanaan program Pengabdian bagi masyarakat ini bertujuan untuk: (1) memotivasi dan mengedukasi masyarakat tentang betapa pentingnya melakukan sesuatu yang bermanfaat guna memenuhi kebutuhan asupan pangan secara mandiri, (2) mengoptimalisasikan teknologi hydroponic dengan pembangunan greenhouse, (3) meningkatkan potensi yang dimiliki masyarakat melalui kegiatankegiatan penyuluhan dan pendampingan penanaman sayuran dengan media air, (4) meminimalisir hama tanaman sehingga memaksimalkan hasil produksi. Metode yang digunakan dalam kegiatan ini lebih menekankan kepada penyampaian informasi/edukasi melalui kegiatan penyuluhan yang terpola dan terstruktur, pendampingan dan evaluasi yang berkesinambungan. Simpulan dari kegiatan ini adalah (1) Menambah pengetahuan warga tentang pentingnya melakukan sesuatu yang bermanfaat guna memenuhi kebutuhan asupan pangan secara mandiri; (2) Kegiatan pengabdian ini memberikan edukasi kepada warga mengenai bagaimana cara memanfaatkan lahan kebun ataupun pekarangan rumah untuk membudidayakan sayuran menggunakan teknologi hydroponic dengan pembangunan greenhouse, sehingga bisa meminimalisir hama dan memaksimalkan hasil produksi; dan (3) Warga masyarakat sangat antusias mengikuti setiap tahapan kegiatan pengabdian ini.
\end{abstract}

Kata kunci: Greenhouse, Hydroponic, Pangan

\section{Abstract}

The difficulty of meeting the food needs of the people of Kampung Ciganda should not need to occur. Seeing some of the potential it has, such as the size of the garden area and the majority of the people who work as farmers. However, due to limited water availability during the dry season, vegetable yields are often not optimal. Another factor that causes crop failure is the attack of vegetable pests. The implementation of the Community Service Program aims to: (1) motivate and educate the public about the importance of doing something useful to meet their food intake needs independently, (2) optimizing hydroponic technology by building greenhouses, (3) increase the potential of the community through outreach activities and assistance in planting vegetables with water media, (4) minimize plant pests so as to maximize production yields. The method used in this activity emphasizes the delivery of information/education through patterned and structured counseling activities, continuous mentoring and evaluation. The conclusions of this activity are (1) Increase the knowledge of residents about the importance of doing something useful in order to meet the needs of food intake independently; (2) This service activity provides education to residents on how to use garden land or home yards to cultivate vegetables using hydroponic technology with greenhouse construction, so as to minimize pests and maximize production results; and (3) Community members are very enthusiastic about participating in each stage of this service activity.

Keywords: Food, Hydroponic, Greenhouse

\section{PENDAHULUAN}

Kebutuhan pangan merupakan kebutuhan primer yang harus dipenuhi agar kelangsungan hidup seseorang dapat terjamin. Kebutuhan pangan itu meliputi makanan pokok, buah-buahan, sayur-mayur, dan lauk pauk. Indonesia adalah salah satu negara berkembang yang sejak awal 
dikenal sebagai negara agraris. Namun, dewasa ini Indonesia justru menghadapi masalah serius dalam hal pengadaan pangan. Indonesia menghadapi keadaan yang semakin sulit untuk mencapai, mempertahankan, dan meningkatkan kualitas keberlanjutan ketahanan pangan (Suryana, 2014). Sesungguhnya ini adalah satu ironi, karena sebagai negara yang memiliki beragam sumber pangan seharusnya Indonesia bisa memenuhi kebutuhan akan pangan tanpa harus bergantung pada negara lain. Terlebih lagi sejak pandemi covid-19 melanda Indonesia pada awal Maret 2020, keluhan utama sebagian besar masyarakat adalah bagaimana menyambung hidup sehari-hari untuk keperluan pemenuhan pangan Khomsan (2020). Kondisi kehidupan saat ini ibarat kiamat kecil yang membuat perekonomian keluarga begitu terpuruk. Kondisi seperti ini juga dirasakan oleh sebagaian besar masyarakat yang berada di Desa Mekarjaya yang Sebagian warganya tidak memiliki pekerjaan karena terdampak pemutusan hubungan kerja (PHK).

Desa Mekarjaya berada di Kecamatan Sukaraja Kabupaten Tasikmalaya yang luasnya sekitar 900,10 hektar. Kondisi geografis didominasi oleh bentuk permukaan datar sampai dengan agak curam. Jumlah penduduk Desa Mekarjaya sekitar 6.106 orang. Terdapat Empat Dusun/ Kepunduhan di Desa Mekarjaya, salah satunya adalah Dusun Cijoho. Kampung Ciganda RT. 01 RW.01 berada di Dusun Cijoho, yang terdiri dari 56 Kepala Keluarga. Mata pencaharian masyarakatnya beraneka ragam, mayoritas berprofesi sebagai petani, buruh tani, dan pedagang. Disamping itu, tidak sedikit pula dari warganya yang pergi ke kota-kota besar untuk bekerja dan mengadu nasib di sana.

Pada sektor pertanian, masyarakat Kampung Ciganda mengandalkan air hujan untuk mengairi area kebun. Hal ini berdampak pada saat musim kemarau, dimana pemanfaatan area kebun menjadi kurang optimal. Padahal, mayoritas masyarakat di Kampung Ciganda ini memiliki area kebun yang cukup luas, sehingga untuk penyiraman sayuran memerlukan air yang cukup banyak. Namun karena ketersediaan air saat musim kemarau sedikit, maka hasil panen sayuran seringkali tidak optimal. Faktor lain yang menyebabkan terjadinya gagal panen adalah serangan hama sayuran. Hal ini berdampak pada hasil panen yang didapatkan tidak maksimal bahkan banyak yang gagal panen. Untuk meminimalisir serangan hama tersebut, pada sayuran yang ditanam, masyarakat Kampung Ciganda menggunakan pestisida cair yang disemprotkan secara berkala kepada sayuran yang ditanamnya. Penggunaan pestisida dalam jangka panjang ini, tentunya memberikan dampak yang buruk terhadap kesehatan masyarakat.

Berdasarkan uraian tersebut, kesulitan akan pemenuhan kebutuhan pangan yang dialami oleh masyarakat Kampung Ciganda seharusnya tidak perlu terjadi. Melihat beberapa potensi yang dimiliki seperti luasnya area kebun, serta masyarakatnya yang mayoritas berprofesi sebagai petani merupakan satu modal yang cukup besar untuk peningkatan ekonomi keluarga di Kampung Ciganda melalui penjualan hasil kebun berupa sayuran. Optimalisasi teknologi hydroponic dengan pembangunan greenhouse di Desa Mekarjaya, diharapkan dapat menjadi solusi untuk mengatasi kesulitan masyarakat dalam menghadapi pandemi Covid-19, khususnya mengenai ketahanan pangan.

Greenhouse merupakan bangunan khusus yang berfungsi sebagai sarana bertanam untuk membantu tanaman agar dapat tumbuh lebih optimal, baik dalam hal pembibitan, penyimpanan ataupun proses budidaya tanaman itu sendiri. Membangun greenhouse sangat berguna untuk menjaga tanaman dari kondisi lingkungan yang tidak menguntungkannya, baik terhadap faktor sinar matahari, kelembaban, suhu, angin, cuaca, maupun terhadap serangan hama penyakit, sehingga dapat diperoleh hasil tanaman yang lebih baik. Hal senada diungkapkan oleh Tando (2019) yang menyatakan bahwa taknologi greenhouse atau rumah tanaman dapat menjadi sebuah alternatif solusi untuk mengendalikan kondisi iklim mikro pada tanman.

Secara umum, manfaat greenhouse bagi tanaman, antara lain: (1) dapat menanam tanpa mengenal musim; (2) Meningkatkan kualitas dan kuantitas hasil produksi; (3) Memungkinkan budidaya secara organik; dan (4) terlindung dari hama tanaman (bibitonline.com). Sedangkan hydroponic adalah suatu budidaya menanam dengan mamakai (memanfaatkan) air tanpa memakai tanah dan menekankan penumbuhan kebutuhan nutrisi untuk tanaman. Kebutuhan air pada tanaman hidroponik lebih sedikit dibandingkan kebutuhan air pada budidaya dengan memakai media tanah. Hidroponik memakai air yang lebih efisien, jadi sangat cocok diterapkan pada daerah yang mempunyai pasokan air yang terbatas. Disamping itu, teknologi budidaya 
pertanian sistem hidroponik memberikan alternatif bagi para petani yang memiliki keterbatasan lahan sehingga dapat melaksanakan kegiatan usaha yang dapat dijadikan sebagai sumber penghasilan yang memadai (Roidah, 2014; Putro \& Sopyan, 2020).

Dengan mengoptimalisasikan teknologi hydroponic dengan pembangunan greenhouse diharapkan dapat mengatasi berbagai permasalahan yang dihadapi masyarakat Kampung Ciganda, minimalnya untuk pemenuhan kebutuhan pangan bagi setiap anggota keluarga. Hal ini sejalan dengan Peraturan Pemerintah Nomor 17 Tahun 2015 tentang Ketahanan Pangan dan Gizi dimana dalam Pasal 26 mengamanatkan bahwa upaya penganekaragaman pangan salah satunya dilakukan melalui optimalisasi pemanfaatan lahan pekarangan. Dengan terlaksananya program $\mathrm{PbM}-\mathrm{KP}$ ini, setidaknya ancaman krisis pangan yang disinyalir oleh Food Agriculture Organization (FAO), dapat diantisipasi manakala setiap rumah tangga mampu memproduksi bahan pangan dari pekarangan rumahnya sendiri (tempo.co, 2020).

Tujuan dari penulisan ini adalah untuk memberikan informasi dan edukasi mengenai optialisasi teknologi hydroponic dengan pembangunan greenhouse sebagai solusi ketahanan pangan bagi masyarakat Kampung Ciganda dimasa pandemi.

\section{METODE}

Metode/pendekatan yang digunakan lebih menekankan kepada penyampaian informasi/ edukasi kepada masyarakat melalui kegiatan penyuluhan yang terpola dan terstruktur mengenai optimalisasi teknologi hydroponic dengan pembangunan greenhouse, serta pendampingan dan evaluasi yang berkesinambungan tentang proses penanaman sayuran menggunakan media air (hydroponic) mulai dari penyemaian, penanaman, sampai dengan panen. Untuk mengatasi berbagai persoalan yang dihadapi oleh masyarakat, maka diperlukan langkah-langkah sebagai berikut:

\subsection{Persiapan}

Pada tahap persiapan, pengusul berkoordinasi dengan Ketua RT dan RW selaku mitra untuk mensosialisasikan kegiatan ini kepada masyarakat. Selanjutnya, pengusul bersama dengan mitra melaksanakan analisis kebutuhan dengan melakukan observasi secara langsung kepada masyarakat setempat, guna melakukan pemetaan lahan yang dapat dimanfaatkan untuk pembangunan greenhouse, pemetaan sumber daya, antusiasme warga, dan lain-lain. Selanjutnya dari hasil pengamatan ini, pengusul melakukan Focus Group Discussion (FGD) bersama mitra, guna menentukan strategi yang akan diambil pada saat pelaksanaan program dan mempersiapkan segala sesuatu yang diperlukan.

\subsection{Pelaksanaan}

Pada tahap pelaksanaan, pengusul memberikan informasi/ edukasi kepada masyarakat melalui penyuluhan-penyuluhan yag dilaksanakan secara terpola dan terstruktur, meliputi:

1. Pembangunan Greenhouse

Pada kegiatan awal, dilakukan pembangunan greenhouse. Sebelum proses pembangunan, masyarakat Kampung Ciganda diberikan edukasi mengenai manfaat dan kegunaan dari greenhouse ini. Dalam pertemuan ini juga, warga ikut serta dalam pembangunan greenhouse. Warga diperkenalkan dengan bahan-bahan yang dibutuhkan sampai dengan melihat dan membantu dalam proses pembangunannya. Membangun greenhouse sangat berguna untuk menjaga tanaman dari kondisi lingkungan yang tidak menguntungkannya, baik terhadap faktor sinar matahari, kelembaban, suhu, angin, maupun terhadap serangan hama penyakit, sehingga dapat diperoleh hasil tanaman yang lebih baik.

2. Penyuluhan I

Penyuluhan tentang teknologi hydroponic sekaligus praktik menyemai benih sayuran dengan menggunakan media rockwool dan cara penggunaan nutrisi untuk persiapan budidaya.

3. Penyuluhan II

Praktik menanam sayuran yang telah disemai dan penggunaan nutrisi organik. Pada kegiatan 
ini, pengusul memberikan informasi/edukasi kepada masyarakat tentang bagaimana cara menyiapkan media tanam hydroponic yang baik dan benar, beserta perawatan dan pemeliharaannya.

\subsection{Pendampingan dan Evaluasi}

Pada tahap ini, pengusul beserta mitra melakukan pendampingan dan monitoring terhadap masyarakat. Hal ini dilakukan untuk melihat kemajuan masyarakat Kampung Ciganda dalam mengelola/ membudidayakan sayuran yang telah ditanam sebelumnya pada greenhouse dengan menggunakan teknologi hydroponic, beserta kendala-kendala yang dihadapi untuk dicarikan solusi penyelesaiannya.

\section{HASIL DAN PEMBAHASAN}

Kegiatan pengabdian pada masyarakat diawali dengan penjajagan ke lokasi pengabdian yaitu di Kp. Ciganda RT. 01 RW. 01 Desa Mekarjaya Kecamatan Sukaraja Kabupaten Tasikmalaya pada tanggal 06 Mei 2021. Penjajagan ke lokasi bertujuan untuk memperoleh data mengenai kondisi pertanian khususnya dalam penanaman sayuran dan permasalahannya di desa tersebut. Pada hari itu, kami di sambut oleh pak RT. 01 yaitu Bapak Apip Purmawan dan koordinator bidang pertanian di Kp. Ciganda untuk mendapatkan informasi-informasi seputar kegiatan yang akan dilaksanakan.

Berdasarkan hasil wawancara dan diskusi dengan Ketua Ketua RT. 01 dan koordinator bidang pertanian, menyatakan bahwa pandemi Covid-19 yang telah melanda sejak bulan Maret 2020 memberikan dampak yang sangat signifikan terhadap perekonomian warga Kampung Ciganda. Apalagi saat pemerintah Provinsi Jawa Barat memberlakukan/menetapkan Pembatasan Sosial Berskala Besar (PSBB) untuk wilayah Kabupaten Tasikmalaya dan sekitarnya. Sebagian besar warga Kp. Ciganda banyak mengalami kesulitan, terutama dalam hal pemenuhan kebutuhan sehari-hari khususnya pangan. Selain itu, banyaknya warga yang pulang kampung karena terimbas Pemutusan Hubungan Kerja (PHK) di tempat mereka bekerja, sehingga angka pengangguran di Kampung Ciganda meningkat.

Berdasarkan uraian tersebut, kesulitan akan pemenuhan kebutuhan pangan yang dialami oleh masyarakat Kampung Ciganda seharusnya tidak perlu terjadi. Melihat beberapa potensi yang dimiliki, hampir seluruh warga di Desa Ciganda memiliki potensi lahan kebun dengan luas beragam antara $50 \mathrm{~m}^{2}-150 \mathrm{~m}^{2}$, bahkan banyak yang lebih luas dari itu. Berdasarkan hasil diskusi tersebut diketahui bahwa masyarakat di Desa Mekarjaya sebagian telah memanfaatkan lahan kebun untuk kegiatan budidaya pertanian, namun ada juga yang tidak di manfaatkan. Sebetulnya mayoritas dari warga masyarakat berprofesi sebagai petani merupakan satu modal yang cukup besar untuk menjadikan setiap keluarga di Kampung Ciganda ini tidak mengalami kesulitan akan pangan. Pemanfaatan lahan kebun dapat mereka gunakan untuk menanam beberapa jenis makanan pokok, buah-buahan terlebih sayuran.

Masyarakat Desa Mekarjaya yang mayoritas berprofesi sebagai petani, seharusnya tidak asing dengan bagaimana cara menanam benih sayuran seperti kangkung, bayam, pakcoy, seledri, bawang daun, tomat, cabai rawit, dan lain-lain. Tetapi pada kenyataannya masih banyak ditemukan beberapa kendala. Permasalahan yang umum dijumpai dalam penanaman benih sayuran tersebut adalah ketidak tahuan masyarakat mengenai media tanam. Kendala lain yang ditemukan diantaranya minimnya kesediaan air, banyaknya hama, minimnya edukasi masyarakat tentang jenis benih yang digunakan, serta lamanya masa tanam mencapai dua sampai tiga bulan. Selain kenkdala-kendala yang telah diungkapkan warga Kp. Ciganda juga tidak semua memiliki edukasi tentang teknik menanam sayuran mulai dari menyemai benih sampai pemindahan hasil dari penyemaian kedalam media tanam.

Kaitannya dengan media tanam yang digunakan, kebanyakan masyarakat hanya menggunakan media tanah dikebun mereka sebagai media tanam, yang lama-kelamaan kalau tidak kelola dengan baik media yang digunakan akan mengeras sehingga pertumbuhan tanaman tidak optimal. Selain itu pada budidaya sayuran, keterbatasan biaya dalam membeli benih-benih 
sayuran pun menjadi salah satu kendala. Bagi sebagian besar warga tentunya merasa kesulitan jika harus mengeluarkan biaya ekstra untuk membeli benih-benih sayuran tersebut. Dimasa sulit ini, mereka lebih mengutamakan kebutuhan pokok sehari-hari dari pada harus mengeluarkan biaya ekstra untuk hal-hal lain.

Selain itu, berdasarkan hasil observasi dan wawancara, didapatkan informasi bahwa masa tanam sayuran yang mereka anggap paling cepat itu mencapai dua sampai tiga bulan. Salah satu penyebabnya dikarenakan sistem pertanian di daerah tersebut mengandalkan air hujan sebagai sumber pengairan. Saat musim kemarau, sawah-sawah dan kebun-kebun di daerah itu kurang dimanfaatkan secara optimal. Oleh karena itu, perlu dipikirkan solusi terbaik untuk mengatasi persoalan tersebut.

Melihat beberapa informasi mengenai berbagai permasalahan yang dihadapi warga Desa Mekarjaya dan berbagai potensi yang dimilikinya, maka dalam pertemuan pertama disepakati bahwa kegiatan pelatihan nantinya difokuskan pada kegiatan penyuluhan untuk memotivasi dan mengedukasi masyarakat tentang betapa pentingnya melakukan sesuatu yang bermanfaat guna memenuhi kebutuhan asupan pangan secara mandiri, serta penyuluhan dan praktik tentang penggunaan media tanam selain tanah. Pada penyuluhan ini memberikan edukasi tentang pemanfaatan teknologi hydroponic kepada masyarakat mengenai penggunaan media air sebagai media tanam sayuran yang tidak memerlukan banyak air selama proses budidaya sayurannya dan lama masa tanam sayuran lebih cepat, kisaran 21 sampai 40 hari. Pada saat kegiatan nanti akan mempelajari bagaimana cara menyiapkan media tanam dengan menggunakan media air (hydroponic) dan cara menanam sayuran yang baik dan benar, beserta perawatan dan pemeliharaannya. Disamping itu karena ada kendala hama dalam penanaman sayuran maka akan diberikan edukasi tentang pembuatan greenhouse kepada masyarakat sebagai salah satu alternatif untuk meminimalisir serangan hama.

Setelah dilakukan penjajagan, kegiatan selanjutnya yang dilakukan adalah penyuluhan dan praktik tentang bagaimana cara menyiapkan pipa untuk media tanam air dan pembuatan greenhouse. Kegiatan penyuluhan dan pelatihan pertama dilaksanakan pada tanggal 14 agustus 2021 di Kp. Ciganda RT/RW 01/01 Desa Mekarjaya. Yang hadir pada pertemuan pertama ada 6 orang karena yang lain ada kegiatan lain.

Pada kegiatan penyuluhan dan praktik di pertemuan pertama, terlihat sekali antusiasme warga selama kegiatan berlangsung. Banyak sekali keingintahuan dari warga mengenai materi yang disampaikan. Pada pertemuan tersebut, warga terjun langsung membangun grueenhose yang sebagian tersedia disana. Hal ini dimaksudkan agar warga dapat melihat dan mengetahui hasil akhir dari praktik yang sedang dilaksanakan bahkan mampu membangun sendiri greenhosenya. Pembuatan greenhouse memanfaatkan bambu yang sudah tersedia di daerah tersebut disajikan pada Gambar 1.

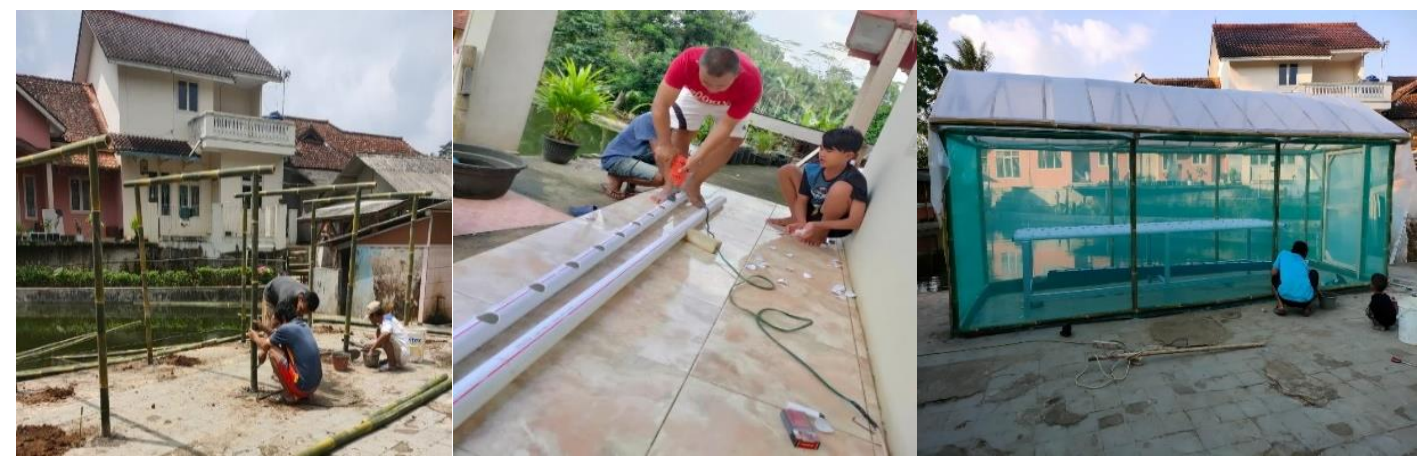

Gambar 1. Pelatihan Pembuatan Greenhouse

Pertemuan kedua dilaksanakan pada hari Minggu tanggal 22 Agustus 2021. Seperti biasa, tepat pukul 08.00 wib, tim pengabdian berkumpul dilokasi yang telah ditentukan. Selama kurang lebih satu jam setengah, kami pun tiba di Desa Mekarjaya. Kegiatan pada pertemuan kedua sekitar pukul 10.00 wib, diawali dengan pemberian bahan-bahan yang akan digunakan untuk tanaman hydroponic dan benih sayuran kepada warga. 
Kegiatan pertemuan kedua dilanjutkan dengan penyuluhan dan edukasi tentang penggunaan bahan-bahan untuk media tanam hydroponic. Warga diberikan penyuluhan dari mulai bagaimana cara memotong rockwool yang akan digunakan untuk media semai. Setelah rockwool selesai dipotong dilanjutkan dengan edukasi dan praktik cara menyemai dengan menggunakan media rockwool. Pada pertemuan ini benih yang disemai adalah sayuran pakcoy (Nauli F1). Berikut suasana penyerahan bahan-bahan dan benih sayuran kepada warga untuk selanjutnya dibudidaya secara mandiri oleh warga sekaligus praktik menyemai dengan media rockwool.

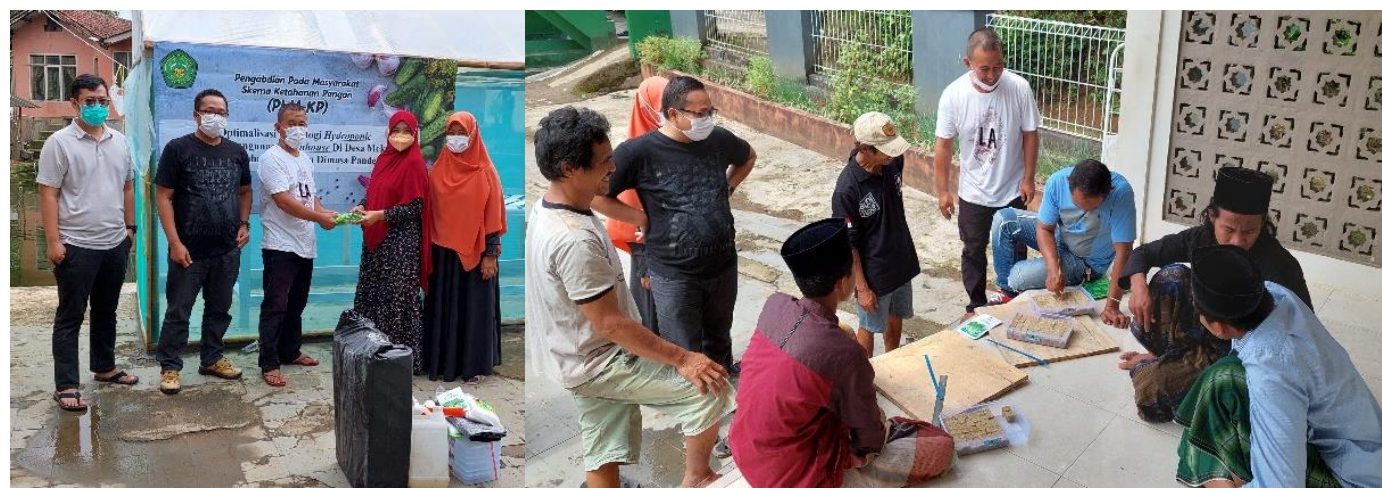

Gambar 2. Suasana Pendistribusian bahan-bahan dan benih sayuran sekaligus praktik menyemai dengan media rockwool

Kegiatan pertemuan ketiga dilanjutkan dengan penyuluhan dan evaluasi tentang hasil penyemaian benih sayuran pakcoy yang telah dilakukan oleh warga pada pertemuan sebelumnya. Hasil benih yang telah disemai oleh warga pada tanggal 22 Agustus 2021 lalu, sudah siap untuk ditanam. Dari kegiatan tersebut, warga memperoleh banyak informasi dan pengalaman.

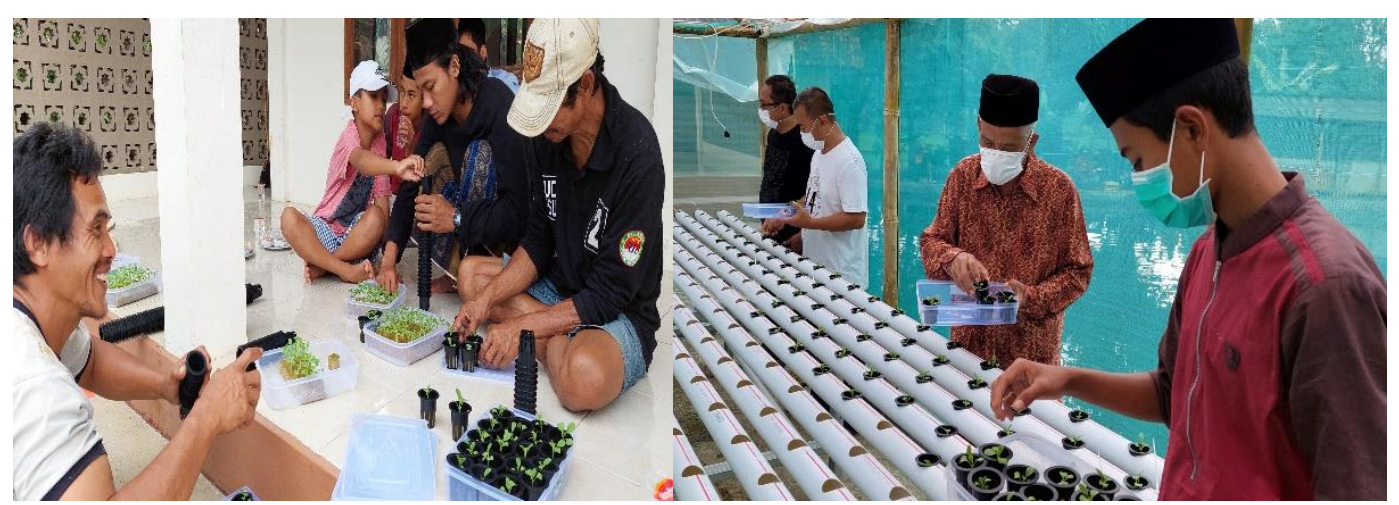

Gambar 3. Edukasi mengenai Hasil Penyemaian Benih Sayuran dan Menanam Hasil Semai

Kegiatan selanjutnya adalah penyuluhan dan praktik bagaimana cara menggunakan nutrisi untuk tanaman hydroponic. Pencampuran nutrisi dengan air (pekatan) dilakukan didalam botol jerigen sebanyak dua (2) buah jerigen masing-masing 5 liter yang terdiri dari nutrisi pekatan A dan nutrisi pekatan B yang biasa disebut AB Mix. Setelah proses pencampuran selesai, maka hasil campuran tersebut dimasukkan kedalam penampung air (ember) dengan perbandingan 1:1 untuk menambah kadar PPM yang dibutuhkan oleh tanaman hydroponic. PPM yang merupakan singkatan dari "Part Per Million" atau "Sepersejuta Bagian" adalah satuan untuk mengukur kepekatan suatu larutan cair. Dalam sistem hydroponic PPM digunakan untuk mengukur tingkat kepekatan larutan nutrisi. Setiap tanaman membutuhkan PPM yang berbedabeda. Agar bisa tumbuh maksimal, pemberian nutrisi juga harus tepat. Penggunaan PPM yang diperlukan untuk beberapa jenis sayuran, disajikan pada Tabel 1. 
Tabel 1. Jenis sayuran dan PPM yang dibutuhkan

\begin{tabular}{lllll}
\hline \multirow{2}{*}{ Jenis sayuran } & \multicolumn{4}{c}{ PPM } \\
\cline { 2 - 5 } & Minggu ke-1 & Minggu ke-2 & Minggu ke-3 & Minggu ke-4 \\
\hline Kangkung & 500 & 800 & 1200 & 1200 \\
Pakcoy & 500 & 700 & 900 & 1200 \\
Bayam & 500 & 700 & 700 & 1200 \\
Selada & 500 & 700 & 700 & 840 \\
Kailan & 500 & 700 & 900 & 1200 \\
\hline
\end{tabular}

Berdasarkan Tabel 1 besarnya PPM yang dibutuhkan rata-rata berkisar antara 500-1200. Jenis-jenis sayuran tersebut sebenarnya sudah dapat dipanen di minggu ke-2 tergantung ukuran sayuran yang diinginkan.

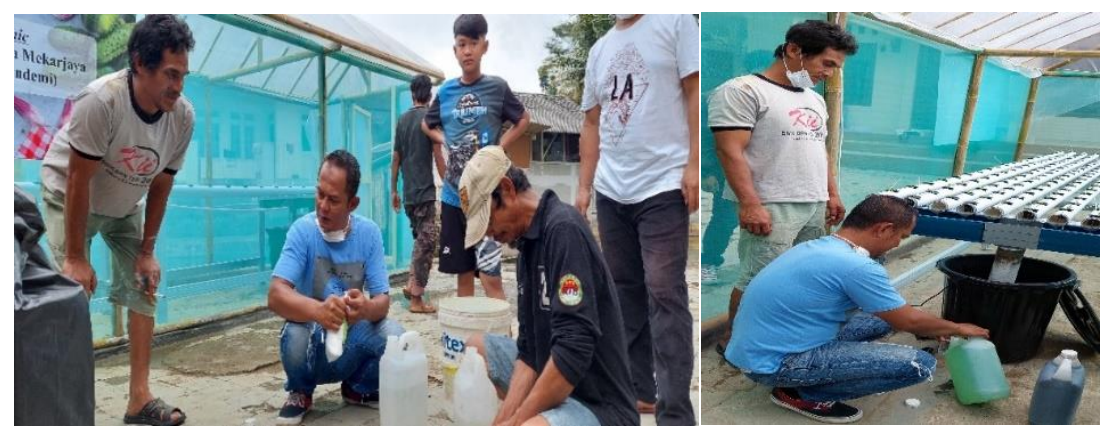

Gambar 4. Edukasi Mengenai Penggunaan Nutrisi

Pertemuan keempat yang dilaksanakan pada hari Sabtu tanggal 19 September 2021, tim pengabdian pun meluncur kembali ke Desa Mekarjaya untuk melaksanakan monitoring dan evaluasi proses penanaman sayuran pakcoy. Pada pertemuan kali ini, kami melihat secara langsung wajah berseri-seri dari warga karena melihat hasil panen sayuran pakcoy yang hasilnya sangat memuaskan. Kegiatan pendampingan dan evaluasi dapat dilihat pada Gambar 5.

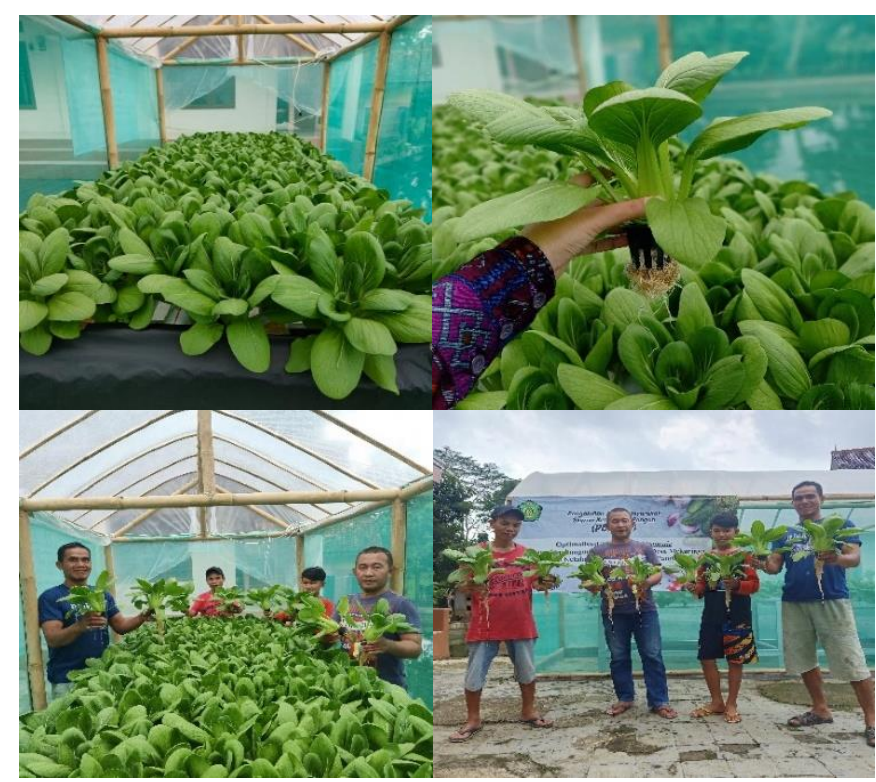

Gambar 5. Kegiatan Pendampingan dan Evaluasi

Indikator keberhasilan kegiatan setelah dilaksnakannya kegiatan pengabdian bagi masyarakat ini adalah (1) evaluasi kegiatan pengabdian dilakukan dengan cara membandingkan pengetahuan dan pemahaman warga sebelum dan sesudah kegiatan. Secara umum dapat menunjukkan bahwa terjadi peningkatan pengetahuan warga mengenai teknologi hydroponic 
dengan pembangunan greenhouse dalam pertanian sebagai solusi ketahanan pangan dimasa pandemi di Desa Mekarjaya Kecamatan Sukaraja Kabupaten Tasikmalaya; (2) warga memahami bahwa pemanfaatan media Air secara optimal dalam pertanian dapat mempercepat masa panen dan dengan adanya greenhouse dapat meminimalisir datangnya hama; dan (3) strategi pemberian materi baik waktu maupun tempat terutama penyuluhan di lapangan dirasakan sangat mendukung kegiatan karena warga mempunyai banyak waktu untuk mengikuti kegiatan penyuluhan. Kriteria dan indikator keberhasilan pelaksanaan kegiatan pengabdian ini, disajikan pada Tabel 2 .

Tabel 2. Indikator Keberhasilan Kegiatan Pengabdian

\begin{tabular}{|c|c|}
\hline Kriteria & Indikator \\
\hline Tingkat Partisipasi & $\begin{array}{l}\text { Kegiatan penyuluhan selalu dihadiri seluruh peserta yang jumlahnya } \\
\text { sebanyak } 10 \text { orang warga. }\end{array}$ \\
\hline Tingkat & Peserta aktif bertanya dan sering mengemukakan saran-saran serta ide- \\
\hline Pemahaman & ide atau pengetahuan yang mereka punya serta meminta saran ilmiah \\
\hline Peserta terhadap & terhadap ide yang mereka kemukakan. Peserta sangat serius mengikuti \\
\hline Materi Penyuluhan & penyuluhan. \\
\hline Dampak & Dari tahapan demi tahapan penyuluhan ini terlihat antusias peserta dan \\
\hline Penyuluhan & $\begin{array}{l}\text { terlihat diskusi semakin hidup dan peserta menguasai permasalahan } \\
\text { yang mendasar mengenai pemanfaatan media air dalam teknologi } \\
\text { hydroponic dengan pembangunan greenhouse. }\end{array}$ \\
\hline Kesesuaian Materi & $\begin{array}{l}\text { Materi penyuluhan sangat relevan dengan permasalahan yang sedang } \\
\text { dihadapi. Dengan adanya penyuluhan dan edukasi tentang teknologi } \\
\text { hydroponic dan dengan adanya greenhouse percontohan, diharapkan } \\
\text { warga dapat membuatnya di pekarangan tempat tinggal masing-masing }\end{array}$ \\
\hline
\end{tabular}

\section{KESIMPULAN}

Berdasarkan uraian pelaksanaan kegiatan pengabdian ini, maka dapat ditarik kesimpulan sebagai berikut: (1) Kegiatan pengabdian ini dapat dikategorikan berhasil jika dilihat dari tingkat partisipasi peserta, mengingat dalam ketiap kegiatan selalu dihadiri oleh seluruh peserta yang jumlahnya sebanyak 10 orang warga, (2) Para peserta merasa bahwa kegiatan pengabdian ini dapat menambah pengetahuan mereka tentang pentingnya melakukan sesuatu yang bermanfaat guna memenuhi kebutuhan asupan pangan secara mandiri menggunakan teknologi hydroponic dengan pembangunan greenhouse. Dari tahapan demi tahapan penyuluhan ini terlihat antusias peserta dan terlihat diskusi semakin hidup dan peserta menguasai permasalahan yang mendasar mengenai pemanfaatan media air dalam teknologi hydroponic dengan pembangunan greenhouse, dan (3) Para peserta memiliki pengetahuan dan pengalaman dalam menyiapkan media tanam dengan menggunakan media air (hydroponic) dan cara menanam sayuran yang baik dan benar, beserta perawatan dan pemeliharaannya. Peserta juga dapat melakukan penyemaian benih sayuran pada rockwool, mulai dari cara memotong rockwool yang akan digunakan untuk media semai sampai dengan praktik cara menyemai dengan menggunakan media rockwool.

\section{DAFTAR PUSTAKA}

Bibitonline.com. (tanpa tahun). Membuat Green House Sendiri. Tersedia [online] di https://bibitonline.com/artikel/membuat-green-house-sendiri

Gurupendidikan.go.id. (tanpa tahun). Hidroponik. Tersedia [online] di https://www.gurupendidikan.co.id/pengertian-hidroponik/

Khomsan, A. (2020). Ketahanan Pangan dan Gizi di Tengah Covid-19. Tersedia [online] di https://mediaindonesia.com/read/detail/304831-ketahanan-pangan-dan-gizi-di-tengahcovid-19 
Putro, B. E. \& Sopyan, N. A. (2020). Optimalisasi Pemanfaatan Pekarangan untuk Pemberdayaan Pangan Mandiri Berbasis Teknologi Hidroponik. Jurnal IKRAITH-ABDIMAS, 3(3). https://journals.upi-yai.ac.id/index.php/IKRAITH-ABDIMAS/article/view/774

Roidah, S. I. (2014). Pemanfaatan Lahan dengan Menggunakan Sistem Hidroponik. Jurnal $\begin{array}{llll}\text { Universitas Tulungagung Bonorowo. } & \text { 1(2). }\end{array}$ https://journal.unita.ac.id/index.php/bonorowo/article/view/14/11

Suryana, A. (2014). Menuju Ketahanan Pangan Indonesia Berkelanjutan 2025: Tantangan dan Penanganannya. Tersedia [online] di https://media.neliti.com/media/publications/56153ID-menuju-ketahanan-pangan-indonesia-berkel.pdf

Tando, E. (2019). Review: Pemanfaatan Teknologi Greenhouse dan Hidroponik sebagai Solusi menghadapi Perubahan Iklim dalam Budidaya Tanaman Holtikultura. Jurnal Buana Sains. 19(1). https://jurnal.unitri.ac.id/index.php/buanasains/article/view/1530

Tempo.co (2020). Kementan Siapkan Strategi Ketahanan Pangan di Tengah Covid-19. Tersedia [online] di https://nasional.tempo.co/read/1337745/kementan-siapkan-strategi-ketahananpangan-di-tengah-pandemi-covid-19 
Halaman Ini Dikosongkan 